\title{
Behavior of Mortars with Different Porosities in Front of Attack of Aggressive Agents
}

\author{
Alessandra M. Weber ${ }^{1}$, Wellington Mazer $^{2}$, Daniela E. Pedroso ${ }^{3}$ and Cleber Pedroso ${ }^{4}$ \\ ${ }^{1}$ Academic Department of Civil Construction, Federal and Technological University of Parana \\ (UTFPR), Campus Ecoville, Curitiba, Brazil, alessandramoniqueweber@gmail.com \\ ${ }^{2}$ Academic Department of Civil Construction, Federal and Technological University of Parana \\ (UTFPR), Campus Ecoville, Curitiba, Brazil, wmazer@utfpr.edu.br \\ ${ }^{3}$ Academic Department of Civil Construction, Federal and Technological University of Parana \\ (UTFPR), Campus Ecoville, Curitiba, Brazil, danievaniki@hotmail.com \\ ${ }^{4}$ Academic Department of Civil Construction, Federal and Technological University of Parana \\ (UTFPR), Campus Ecoville, Curitiba, Brazil, cleber.ped@gmail.com
}

\begin{abstract}
Chemical reactions that lead to decreased durability in concrete structures may result from chemical interactions between aggressive agents present in the external environment and cement paste compounds or may result from internal reactions. The chemical reactions are manifested by the physical properties of the concrete, such as porosity and permeability and the decrease of resistance and cracking. Among the several aggressive agents that attack the reinforced concrete structures it can be highlighted chloride ions, sulphate ions and carbon dioxide. In this context, the study presents the analysis of different traces of mortar executed with cement type CPII-F-32 (OPC Cement, in Brazil one of the most used cements) with w/c ratios of 0.4 and 0.7 , when subjected to the attack of sulphates, chlorides and carbonation. The analyzes quantitatively evaluated the amount of ions present after exposure to the agents and demonstrate the importance of evaluating the dosage of water in the mortars to minimize future problems with durability.
\end{abstract}

Keywords: Mortars, Sulphate Attack, Chloride Attack, Carbonation, Porosity.

\section{Introduction}

Chemical reactions leading to decreased durability in concrete structures may result from chemical interactions between aggressive agents present in the external environment and cement paste compounds or may result from internal reactions like alkali-aggregate reaction, or from reaction of delayed hydration $\mathrm{CaO}$ and $\mathrm{MgO}$ crystalline, if present in excessive amounts in Portland cement, or electrochemical corrosion of concrete reinforcement. Chemical reactions manifest themselves through the physical failures of concrete such as porosity and permeability, decreased strength and cracking.

Among the various aggressive agents that attack reinforced concrete structures, chloride ions, sulphate ions and carbon dioxide can be highlighted.

Sulphate can be found in soils such as landfills and is a major cause of degradation of cement-based materials. The attack by sulfate ions stands out especially when dealing with marine, underground or sewage handling structures (Mehta and Monteiro, 2014; Wei et al., 2019).

When dissolved sulfate ions $\left(\mathrm{SO}_{4}\right)$ react with hydrated cement paste the two main means of 
sulfate attack are: reaction with hydration products of unhydrated tricalcium aluminate $\left(\mathrm{C}_{3} \mathrm{~A}\right)$ producing ettringite and reaction with calcium hydroxide producing gypsum. Sulfate attack on concrete can manifest as expansion or cracking, leading to increased concrete permeability, structural problems and initiating corrosion processes of reinforcement (Mehta and Monteiro, 2014).

According Mangat and Ojedokun (2019) the chloride concentration of concrete exposed to a chloride environment is a parameter used to characterize the long term chloride resistance of concrete. The presence of chlorides is a cause of the corrosion process in reinforcement of reinforced concrete structures. The structure in an environment that has seawater, sea salt and thaw salts is subject to attack by chlorides. The rate of chloride penetration from the surface to the interior of the concrete depends on: the amount of chloride ions in the environment, the permeability of the concrete and the humidity of the environment (Aguiar, 2011).

Carbonation of concrete is directly linked to the $\mathrm{CO}_{2}$ diffusion coefficient that is determined by Fick's first law, but there are limitations in some parameters, for example $\mathrm{CO}_{2}$ diffusivity yaries over time and strongly depends on the moisture content of the pores. concrete, as well as other variables that may also influence the microstructure of the concrete, such as cure condition, moisture content, location, elapsed time and mixing parameters (Yoon et al., 2007).

In this context, the objective is to analyze different traces of mortars made with type CP II - F32 cement with w/c factors of 0.4 and 0.7 when subjected to the attack of sulfates,

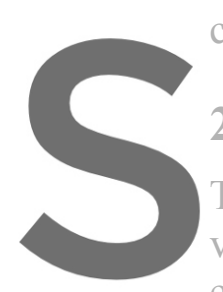
chlorides and carbonation.

\section{Materials and}

To evaluate the durabi verify their performanc evaluation, quantitative tests were performed.
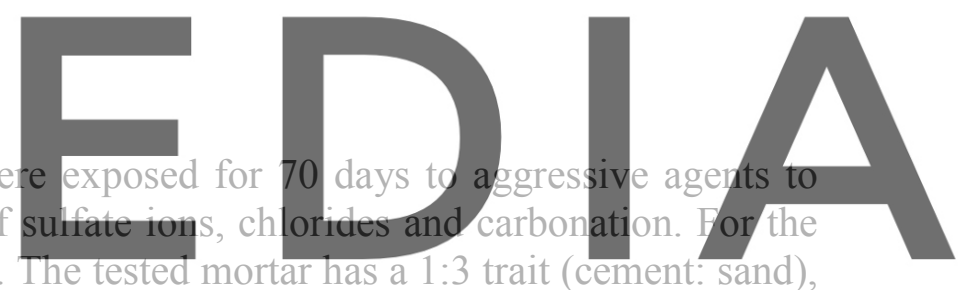
varying the water/cement ratio in two levels, being 0.4 to obtain less porous mortar and w/c of

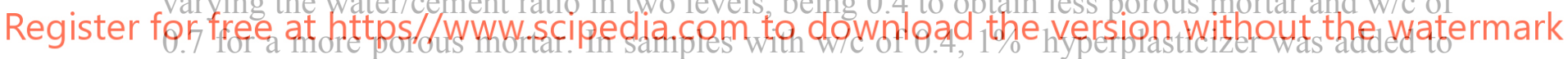

\section{aid in the consistency of the mortar.}

The binder used was Portiand Cement CP II - F32, chosen for its wide availability in the market. The choice of producing mortars is due to the fact of ease in smaller samples, in this case it was decided to mold $10 \times 5 \mathrm{~cm}$ cylindrical specimens. According to some authors such as Papadakis (2000), Kulakowski (2002), Gervais et al. (2004), Pauletti et al. (2007), Pauletti (2009) and Neville (2015) explain about better results that the use of mortar brings in the carbonation front analysis, such as the influence of the presence of coarse aggregate.

For durability analysis against the aggressive agents the specimens were submitted after cure of 28 days in a humid chamber, for the sulfate solution was used $10 \%$ magnesium sulfate $\left(\mathrm{MgSO}_{4}\right)$. For the accelerated chloride attack, $10 \%$ sodium chloride $(\mathrm{NaCl})$ solution was added and for carbonation depth evaluation, the specimens were deposited in a carbonation chamber with $10 \%$ controlled $\mathrm{CO}_{2}$ concentration, without the control of humidity and temperature. 


\subsection{Sulphate Content}

The samples were fully submerged in magnesium sulphate $\left(\mathrm{MgSO}_{4}\right)$ solution of $10 \%$ for up to 70 days. The chemical test to determine the sulphate ions content in the samples was made according to an adaptation of the standard APHA Method 4500-SO ${ }_{4}^{2-}$ (1997). The procedure consists to submit the ground sample, whose diameter is less than $600 \mu \mathrm{m}$, to a solution of hydrochloric acid $(\mathrm{HCl})$, shown in Figure 1, with barium chloride $\left(\mathrm{BaCl}_{2}\right)$, which will form a precipitate of barium sulphate $\left(\mathrm{BaSO}_{4}\right)$, which after calcination at $800^{\circ} \mathrm{C}$ is heavy $\left(\mathrm{M}_{\text {calcined }}\right)$.
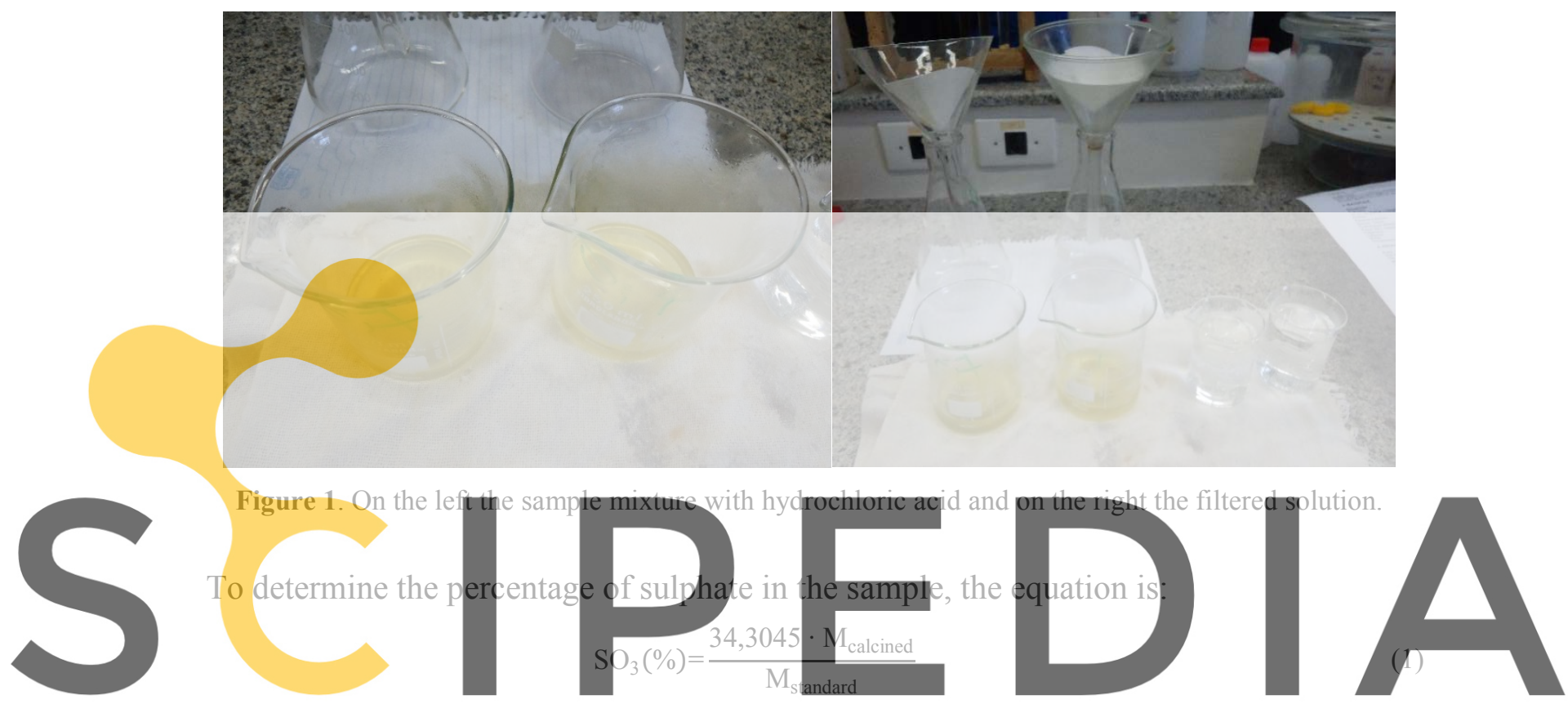

Where the mass of the standard sample is weighed prior to the test in grams.

\section{Register for free at https//www.scipedia.com to download the version without the watermark} 2.2 Chloride Concentration

The chioride concentration of the mortar powder sample was obtained Volinard's titration method. The procedure consists an indirect titration to determine the chloride ion that precipitates with silver ion (Figure 2).

The acid soluble chloride content was calculated as a percentage of chloride ions by weight of the binder, by the following equation:

$$
\mathrm{Cl}^{-}(\%)=0,1773 \cdot \frac{\mathrm{V}_{2}-\mathrm{V}_{1}}{\mathrm{~m}_{1}}
$$

Where V1 is the volume of ammonium thiocyanate of a standard sample in $\mathrm{ml}$, previously determined to be 0,$07 ; \mathrm{V}_{2}$ is the volume of ammonia thiocyanate in the concrete sample in $\mathrm{ml}$; and $\mathrm{m}_{1}$ is the mass of the concrete sample in grams. 


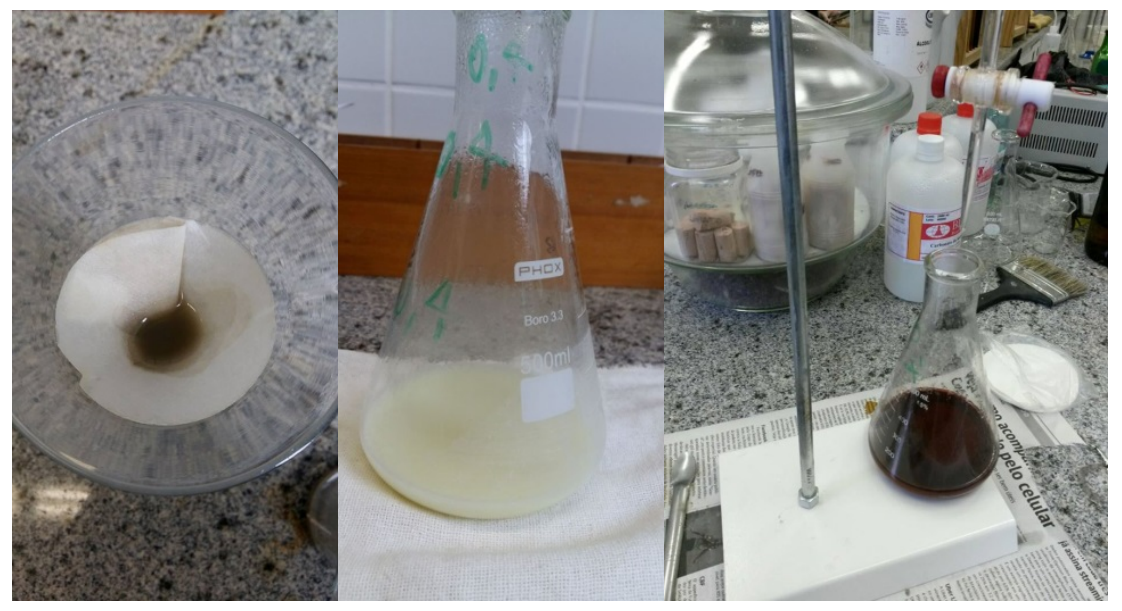

Figure 2. Silver chloride solution filtration and coagulation after boiling and then titanium ammonium titration.

\subsection{Carbonation Penetration}

Carbonation tests were performed by cylindrical mortar samples. Phenolphthalein was used as test to carbonation penetration. It is in the initiation phase that it was intended to verify the occurrence of carbonation, because generally the typical appearance of carbonation is the occurrence of light spots produced by refraction of calcium carbonate, it is necessary to verify

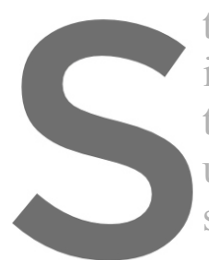
the carbonation using colorimetric indicators that its appearance, tending to the most alkaline region used carbonation or successfully used for pl

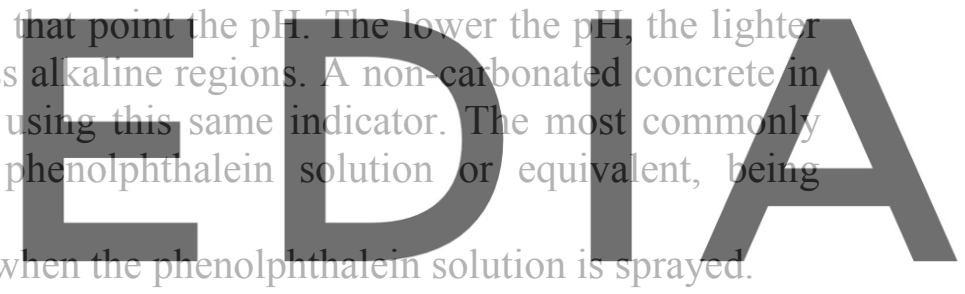

Register for free at https//www.scipedia.com to download the version without the watermark

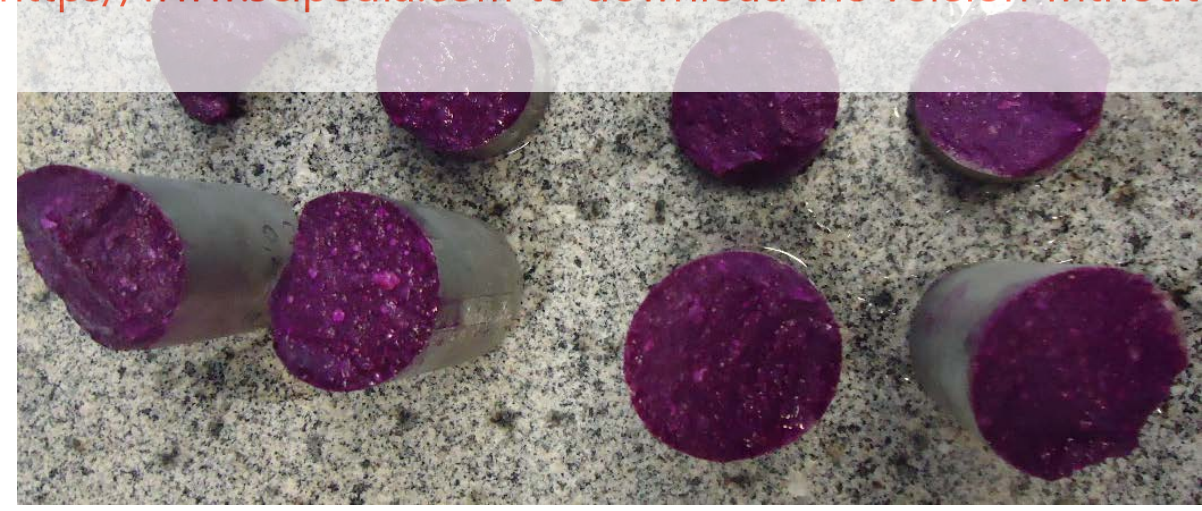

Figure 3. Specimens submitted to the phenolphthalein spray test. 


\section{Results}

The average values of the analyzes of the three tests performed for the sample group, considering the $\mathrm{w} / \mathrm{c}$ variations are presented in Table 1.

Table 1. Mean values for durability analyzes.

\begin{tabular}{ccccc}
\hline Specimens & $\begin{array}{c}\text { Sulphate } \\
\text { content (\%) }\end{array}$ & $\begin{array}{c}\text { Chloride } \\
\text { content }(\%)\end{array}$ & $\begin{array}{c}\text { Carbonation } \\
\text { Penetrarion } \\
(\mathrm{mm})\end{array}$ \\
\hline \multirow{2}{*}{$\mathrm{CP}$ II $-\mathrm{F} 32 \mathrm{w} 2 \mathrm{c} 0.4$} & 6.28 & 0.55 & - \\
\cline { 2 - 5 } & $\mathrm{w} / \mathrm{c} 0.7$ & 8.39 & 0.69 & 2.1 \\
\hline
\end{tabular}

Sulphate content increased by more than $33 \%$ when the water factor used in the mortar was added.

CP II - F32 cement analysis for chloride determination by chloride submerged samples resulted in chloride content of $0.69 \%$ for samples with water/cement ratio of 0.7 and $0.55 \%$ for samples with water/cement ratio of 0.4. According to NBR 12655 (ABNT, 2015) the maximum chloride content for reinforced concrete exposed to chloride in the service conditions of the structure is $0.15 \%$ (considering aggressive classes III and IV, which includes marine and industrial environments with chemical agents). Therefore, all the samples exceeded this reference.

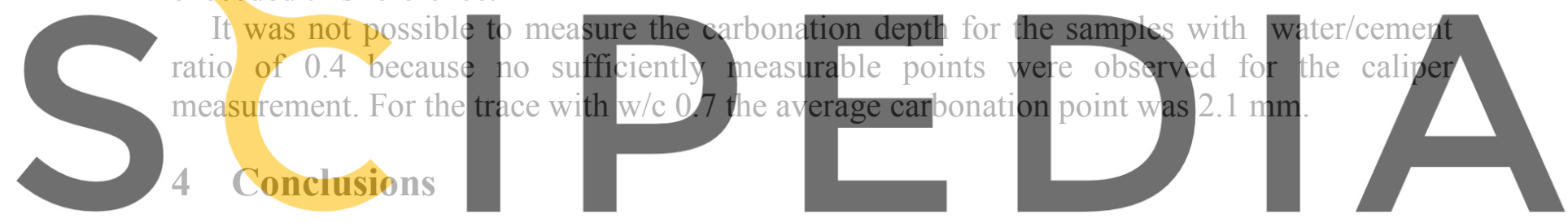

OPC cement mortars using w/c fractions of 0.4 show better durability results when

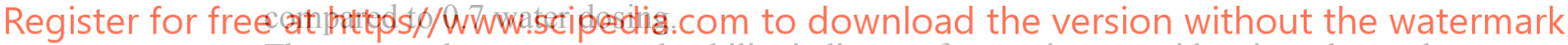

The proposed tests serve as durability indicators for previous considerations due to the attack of sulfates, chlorides and carbonates.

- The service life of concrete structures depends mainly on the durability of the concrete. Concrete made from traditional Portland cement is considered a durable material for the non-aggressive environment, however water should be carefully considered as a direct influence on the durability of mortars and concretes, due to the increased porosity.

\section{ORCID}

Alessandra M. Weber: http://orcid.org/0000-0002-0991-1842

Wellington Mazer: http://orcid.org/0000-0002-9941-999X

Daniela E. Pedroso: http://orcid.org/0000-0003-3077-4544

Cleber Pedroso: http://orcid.org/0000-0002-8265-2920

\section{References}

ABNT (2015). NBR 12655: Concreto de cimento Portland - Preparo, controle, recebimento e aceitação Procedimento, Rio de Janeiro, Brasil.

Aguiar, J.E. (2011). Durabilidade, proteção e recuperação das estruturas, Class Notes, Escola de Engenharia da 
Universidade Federal de Minas Gerais, Belo Horizonte, Brasil.

APHA, (1997). Method 4500-SO ${ }_{4}^{2-}$ - Sulfate. Standard Methods for the Examination of Water and Wastewater. American Public Health Association.

Gervais, C., Garrabrants, A.C., Sanchez, F., Barna, R., Moszkowicz, P. and Kosson, D.S. (2004). The effects of carbonation and drying during intermittent leaching on the release of inorganic constituents from a cementbased matrix. Cement and Concrete Research, 34 (1), 119-131. doi: 10.1016/S0008-8846(03)00248-5

Kulakowski, M.P. (2002). Contribuição ao estudo da carbonatação em concretos e argamassas compostos com adição de sílica ativa, PhD Thesis, Universidade Federal do Rio Grande do Sul, Porto Alegre, Brasil.

Mangat, P.S. and Ojedokun, O.O. (2019). Bound chloride ingress in alkali activated concrete. Construction and Building Materials, 212, 375-387. doi:10.1016/j.conbuildmat.2019.03.302

Mehta, P.K. and Monteiro, P.J. (2014). Concreto: microestrutura, propriedades e materiais. São Paulo: IBRACON.

Neville, A.M. (2015). Propriedades do Concreto. Brasil: Bookman Editora.

Papadakis, V. G. (2000). Effect of supplementary cementing materials on concrete resistance against carbonation and chloride ingress. Cement and concrete research, 30(2), 291-299. doi: 10.1016/S0008-8846(99)00249-5

Pauletti, C. (2009). Estimate of natural carbonation of cement materials based on accelerated tests and prediction models, PhD Thesis, Universidade Federal do Rio Grande do Sul, Porto Alegre, Brasil.

Pauletti, C., Possan, E. and Dal Molin, D.C.C. (2007). Carbonatação acelerada: estado da arte das pesquisas no Brasil. Ambiente construído, 7 (4), 7-20.

Wei, L., Xiao-Guang, J. and Zhong-Ya, Z. (2019). Triaxial test on concrete material containing accelerators under physical sulphate attack. Construction and Building Materials, 206, 641-654. doi: 10.1016/j.conbuildmat.2019.01.186

Yoon, I.S., Çopuroğlu, O. and Park, K.B. (2007). Effect of global climatic change on carbonation progress of concrete. Atmospheric environment, 41 (34), 7274-7285. doi: 10.1016/j.atmosenv.2007.05.028
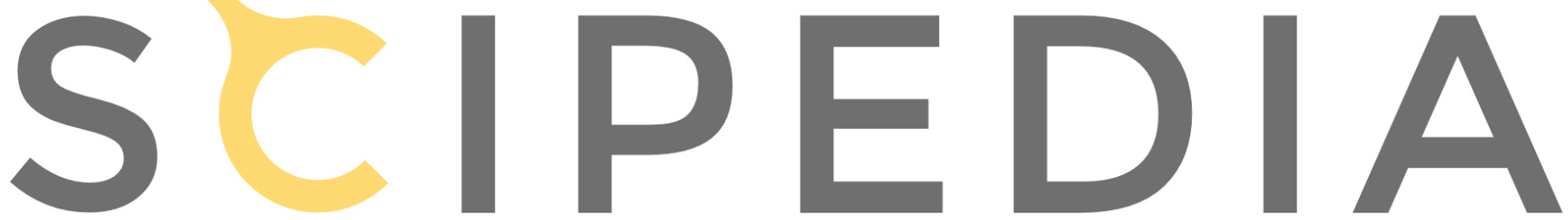

Register for free at https//www.scipedia.com to download the version without the watermark 